\title{
Structural Change, Balance-of-Payments Constraint and Economic Growth: Evidence from the Multi-Sectoral Thirlwall's Law
}

\author{
Raphael Rocha Gouvêa \\ Mestrando em Economia das Instituições e do Desenvolvimento no IPE-USP \\ $\&$ \\ Gilberto Tadeu Lima \\ Professor do Departamento de Economia da FEA-USP
}

\begin{abstract}
This paper contributes to the empirical literature on balance-of-payments-constrained growth by investigating how structural change, identified with change in the sectoral composition of exports and/or imports, affects the extent of the external constraint. This is done by testing both the original and a multi-sectoral version of Thirlwall's Law for a sample of Latin American and Asian countries. While the original, aggregate Thirlwall's Law is found to hold for all sample countries but South Korea, the MultiSectoral Thirlwall's Law is found to hold for all of them. As the sectoral composition of exports and imports is therefore found to matter for growth, we then briefly analyze the evolution of each country's weighted trade income elasticities.
\end{abstract}

Keywords: Structural change, external constraint, Multi-Sectoral Thirlwall's Law.

Resumo: Este artigo contribui para literatura empírica sobre crescimento econômico restrito pelo balanço de pagamentos através da investigação de como a mudança estrutural, identificada como alterações na composição setorial das exportações e/ou importações, afeta a intensidade da restrição externa. Para tanto, testa-se a Lei de Thirlwall original e uma versão multi-setorial desta para uma amostra de países latinoamericanos e asiáticos. A validade da Lei de Thirlwall original é rejeitada apenas para a Coréia, enquanto a Lei de Thirlwall Multi-Setorial não é rejeitada para nenhum dos países. Como esse resultado revela que a composição setorial das exportações e importações importa para o crescimento, é analisada brevemente a evolução das elasticidades-renda ponderadas de cada país.

Palavras-Chave: Mudança estrutural, restrição externa, Lei de Thirlwall Multi-Setorial.

JEL Codes: E10, F43, O19

Classificação Anpec: Área 5 - Crescimento, Desenvolvimento Econômico e Instituições

\footnotetext{
* We are grateful to Anthony Thirlwall for quite helpful comments and suggestions. We have also benefited from useful comments from participants and organizers of the 2008 Summer School on Latin American Economies organized by the Economic Commission for Latin America and Caribbean (ECLAC). Any remaining errors are our own, though. We should also thank research funding granted by The International Celso Furtado Center for Development Policies (Raphael Rocha Gouvêa) and the Brazilian National Council of Scientific and Technological Development (Gilberto Tadeu Lima).
} 


\section{Introduction}

There is both theoretical and empirical support for the view that aggregate demand plays an important role in determining economic growth in the long run. One major argument is that the accumulation of productive capacity in terms of capital and labor is influenced by demand, so that potential output is, to some extent, demand-determined (Setterfield, 2003). In this tradition, a forceful Keynesian demand-oriented approach that emphasizes the external constraints on growth is the so-called theory of 'balance-of-payments-constrained (hereafter BOPC) growth'. According to Thirlwall (1979), given that real exchange rates are constant (or vary negligibly) and that trade must be balanced in the long run, there is a very close correspondence between the growth rate of output and the ratio of exports' growth to the income elasticity of demand for imports. This result became known in the literature as "Thirlwall's Law".

It should be stressed that the BOPC growth approach, despite being demand-oriented, does acknowledge the importance of supply characteristics of goods. Observed differences in the income elasticities of demand for exports and imports reflect the non-price characteristics of goods and, therefore, the structure of production (Thirlwall 1997, p. 383). Indeed, several authors have incorporated the idea that structural change may affect the income elasticities of imports and/or exports in their models (Thirlwall, 1997; Setterfield, 1997; McCombie and Roberts, 2002; Palley, 2002). Meanwhile, one of the most important contributions to the demand-oriented theories of output growth that systematically incorporated structural change is the structural economic dynamics (SED) approach developed by Pasinetti (1981, 1993). One major implication of the SED approach is that changes in the structure of production lead to changes in the rate of growth, due, for instance, to different sectoral rates of demand growth that could be produced by differences in the sectoral income elasticities.

Araujo and Lima (2007) derived a balance-of-payments equilibrium growth rate analogous to Thirlwall's (1979) within a Pasinettian multi-sector macrodynamic framework. The resulting formula, which they call the Multi-Sectoral Thirlwall's Law, asserts that a country's growth rate of per capita income is directly proportional to the growth rate of its exports, with such proportionality being inversely (directly) related to sectoral income elasticities of demand for imports (exports). These elasticities, in turn, are weighted by coefficients that measure the share of each sector in total exports and imports, respectively. Therefore, a major implication of the Multi-Sectoral Thirlwall's Law is that changes in the composition of demand or in the structure of production, which are not reflected in changes in income elasticities but come through changes in the share of each sector in aggregate exports or imports, also matter for economic growth. Given the income elasticites of exports and imports, the original Thirlwall's Law implies that a country's growth rate will rise only when the growth rate of world income increases, whereas the Multi-Sectoral Thirlwall's Law implies that a country can still raise its growth rate even when such a raise in growth of world income does not occur, provided it is able to change the sectoral composition of exports and/or imports accordingly.

In this context, this paper intends to contribute to the empirical literature on BOPC growth by investigating how structural change, identified with change in the sectoral composition of exports and/or imports, affects the extent of the external constraint. This is done by testing both the original and a multisectoral version of Thirlwall's Law for a sample of Latin American (Argentina, Brazil, Colombia and Mexico) and Asian (South Korea, Malaysia, Philippines and Singapore) countries over the period 19622006.

The remainder of the paper is organized as follows. Section 2 briefly derives the original and a multi-sectoral version of Thirlwall's Law, while Section 3 provides a brief review of the related empirical literature and describes the data used in the empirical exercise that followed. In Section 4 we estimate the basic parameters of these BOPC growth models for the sample of Latin American and Asian countries, test the statistical validity of their main predictions and briefly analyze the evolution of each country's weighted trade income elasticities Finally, the last section offers some concluding remarks. 


\section{Balance-of-payments-constrained growth: Aggregate and Multi-Sectoral Thirlwall's Law}

The BOPC growth theory as pioneered by Thirlwall (1979) focuses on the relative income (or growth rate) adjustments required to balance trade at given relative prices (real exchange rate). It postulates that the balance-of-payments position of a country is the main constraint on its growth rate since it imposes a limit on demand to which supply can (usually) adapt. As it turns out, observed differences in growth performance between countries are associated with the relative strength of their balance-of-payments position.

An extension that followed immediately from Thirlwall's (1979) original approach was the work developed by Thirlwall and Hussain (1982), who modified the model to allow for imbalanced trade with capital flows in the long run. As Thirlwall (1979) is therefore a special case of Thirlwall and Hussain (1982), we briefly present the model developed in the latter. The starting point is the following balanceof-payments accounting identity:

$$
P d_{t} X_{t}+F_{t}=P f_{t} E_{t} M_{t}
$$

where $\mathrm{X}$ is the quantity of exports, $\mathrm{M}$ is the quantity of imports, $\mathrm{F}$ is the value of net capital receipts in national currency, with $\mathrm{F}>0(\mathrm{~F}<0)$ measuring net capital inflows (outflows), $\mathrm{Pd}$ is the domestic price level, Pf is the foreign price level, $\mathrm{E}$ is the nominal exchange rate and $\mathrm{t}$ is a time index. By taking natural logarithms and differentiating with respect to time, we obtain a dynamic version of (1):

$$
\theta\left(p_{d t}+x_{t}\right)+(1-\theta) f_{t}=p_{f t}+e_{t}+m_{t}
$$

where the lower case letters denote rates of growth of the variables, and $\theta$ and $(1-\theta)$ denote the shares of exports and capital flows in total foreign currency receipts.

The exports and imports demand functions are assumed to be multiplicative with constant elasticities:

$$
\begin{aligned}
& M_{t}=A\left(\frac{P f_{t} E_{t}}{P d_{t}}\right)^{\psi} Y_{t}^{\pi} \\
& X_{t}=B\left(\frac{P d_{t}}{P f_{t} E_{t}}\right)^{\eta} Z_{t}^{\varepsilon}
\end{aligned}
$$

where $\mathrm{Y}$ is the real product of the country, $\mathrm{Z}$ is the real world product, $\pi$ and $\varepsilon$ are, respectively, the income elasticities of imports and exports, $\psi$ the price elasticity of imports $(\psi<0)$ and $\eta$ the price elasticity of exports $(\eta<0)$. Meanwhile, A and B are constants capturing other effects. Taking growth rates of the variables in (3) and (4), we obtain:

$$
\begin{aligned}
& m_{t}=\psi\left(p_{f t}+e_{t}-p_{d t}\right)+\pi y_{t} \\
& x_{t}=\eta\left(p_{d t}-p_{f t}-e_{t}\right)+\varepsilon z_{t}
\end{aligned}
$$

Substituting (5) and (6) into (2) and solving for the BOPC growth rate, $y_{b p}^{*}$, we obtain:

$$
y_{b p}^{*}=\frac{(\theta \eta+\psi+1)\left(p_{d t}-p_{f t}-e_{t}\right)+\theta \varepsilon z_{t}+(1-\theta)\left(f_{t}-p d_{t}\right)}{\pi}
$$

If it is assumed that relative prices measured in a common currency remain unchanged in the long run, which implies that $\left(p_{d t}-p_{f t}-e_{t}\right)=0$, and that there is no net debt $(\theta=1)$, equation (7) simplifies to the expression for the original Thirlwall's Law:

$$
y_{b p}^{*}=\frac{\varepsilon z_{t}}{\pi}
$$

or: 


$$
y_{b p}^{*}=\frac{x_{t}}{\pi}
$$

Later on, McCombie \& Thirlwall (1997), Moreno-Brid (1998-99) and Barbosa-Filho (2001) extended the model to ensure that the economy's long-run growth is consistent with a sustainable path of foreign indebtedness. However, a major conclusion of the broader literature that considers the possibility of sustainable unbalanced trade is that capital flows are unable to allow an individual country to increase its growth rate above that given by the original Thirlwall's Law by very much or for very long. As argued by McCombie and Roberts (2002), after an allowance is made for capital inflows, under reasonable assumptions regarding sustainability of net foreign capital inflows as a ratio of national income, the effect of these inflows on the balance-of-payments equilibrium growth rate is negligible.

The original Thirlwall's Law thus implies that the only sure and long-term solution to raising a country's growth rate consistent with balance-of-payments equilibrium is structural change to raise its income elasticity of exports and/or to reduce its income elasticity of imports (Thirlwall, 2002, p. 78). Indeed, the view that structural change is likely to affect the income elasticities of exports and imports has been often emphasized in the literature. Bairam (1997) found empirical evidence that the income elasticity of exports is inversely related to the level of per capita income. Thirlwall (1997, p. 381) expresses his concern, however, with the inferences drawn by Bairam, which would imply that developing countries are less balance-of-payments-constrained in their growth than developed countries because the income elasticity of demand for exports is apparently negatively related to the level of per capita income. For Thirlwall, it is dangerous to draw inferences from such a small, selective sample of developing countries that contains mainly newly industrializing countries and very few really poor countries. With a full range of countries from very poor to very rich, Thirlwall would expect an inverted$\mathrm{U}$ relationship showing the income elasticity of exports rising as countries move from primary-product exports to light manufactures and then decreasing as richer countries get locked into antiquated industrial structures. Meanwhile, Setterfield (1997) presented a one-sector model where it is shown that movement through a commodity hierarchy (owing to the generalized operation of Engel's Law) in the course of growth may be hindered by lock-in to a traditional industrial structure which may, in turn, lower the income elasticity of demand for an economy's exports and hence its growth rate. While in Setterfield's (1997) model the income elasticity of demand for an economy's exports is negatively related to its past growth rates of output, McCombie and Roberts (2002) argue that a more appropriate specification would have the ratio of the income elasticity of the demand for exports to the income elasticity of demand for imports being related to previous growth in an inverted- $U$ manner. The intuition is that poor previous growth rates can be expected to give rise to pressure for reforms that lower the ratio of income elasticities, while high previous growth rates can in turn be expected to encourage lock-in of a productive structure. In Pasinetti's $(1981,1993)$ multi-sectoral macrodynamic analysis, in turn, income elasticities for various goods differ and change over time as per capita income increases. As pointed out by Araujo and Lima (2007), while the connection between the structure of production and overall growth is taken up explicitly by Pasinetti $(1981,1993)$ in a multi-sectoral framework, though mostly in the context of a closed economy, the BOPC growth approach developed by Thirlwall (1979) takes it up in the broader context of an open economy, though only implicitly by recognizing that the composition of exports and imports is reflected in their aggregate income elasticities.

Araujo and Lima (2007) then developed a BOPC model for a multi-sectoral economy in which demand varies over time at particular rates in each one of the sectors of two countries. Let A denote the advanced country and $U$ the underdeveloped one. Both countries are assumed to produce n-1 consumption goods. The physical and monetary flows of commodities in country $U$ can be summarized by three conditions, along with the solution for the system of physical and monetary quantities: the full employment condition, full expenditure of national income and trade balance equilibrium. The full employment condition can be stated as:

$$
\sum_{i=1}^{n-1}\left(a_{i n}+\zeta a_{i n}\right) a_{n i}=1
$$


where $a_{i n}$ and $a_{i n}$ are the per capita demand coefficients of final commodity $i$, with $\mathrm{i}=1,2, \ldots . \mathrm{n}-1$. While the former refers to domestic demand, the latter refers to foreign demand. Meanwhile, $a_{n i}$ are the production coefficients of consumption goods, which represent quantities of labor employed in each sector. The household sector in country A is denoted by $\hat{n}$ and the population sizes in both countries are related to each other by the coefficient of proportionality $\zeta$. The condition for full expenditure of national income can be expressed as:

$$
\sum_{i=1}^{n-1}\left(a_{i n}+a_{\text {in }}\right) a_{n i}=1
$$

where $a_{\text {in }}$ is the per capita import demand coefficient for commodity i produced in country A. The trade balance equilibrium is given by:

$$
\sum_{i=1}^{n-1}\left(\zeta a_{i n}-a_{\hat{i n}}\right) a_{n i}=0
$$

An important property of the model, as pointed out by Araujo and Lima (2007), is that the trade balance equilibrium can be written not in terms of prices, as is usual, but in terms of labor coefficients: labor coefficients $a_{n i}$ weight both the export and import demand coefficients for commodities $i$.

The solution of the system for physical quantities can be stated as:

$$
X_{i}=\left(a_{i n}+\zeta a_{\text {in }}\right) X_{n} \quad i=1,2 \ldots ., n-1
$$

where $X_{i}$ is the amount of production of commodity $\mathrm{i}$ and $X_{n}$ is the population of country $\mathrm{U}$. Thus, the physical quantity of each tradable commodity that is produced in country $U$ will be determined by the sum of foreign and domestic demands. With $p_{i}$ being the price of commodity $\mathrm{i}$ in country $\mathrm{U}$, and $w_{u}$ the (uniform) wage rate, the set of solutions for prices can be expressed as:

$$
p_{i}=a_{n i} w_{u} \quad i=1,2 \ldots, n-1
$$

Equation (13) implies that relative quantities of embodied labor continue to regulate relative commodity prices within the boundaries of each country. It is reasonable to assume that if $p_{\hat{i}} \leq p_{i}$, which means that country $U$ does not have a comparative advantage in producing good $i$, then the foreign demand for commodity $\mathrm{i}$ is equal to zero. If $p_{\hat{i}}>p_{i}$, it is assumed that foreign demand for commodity $\mathrm{i}$ is given by a standard export function. These conditions can be expressed as follows:

$$
x_{i n}= \begin{cases}0 & \text { if } p_{\hat{i}}<p_{i} \\ \left(\frac{p_{i}}{p_{\hat{i}}}\right)^{\eta_{i}} Y_{A}^{\beta_{i}} & \text { if } p_{\hat{i}} \geq p_{i}\end{cases}
$$

where $x_{i n}$ is foreign demand for commodity $\mathrm{i}, \eta_{i}$ is the price elasticity of demand for export of commodity $\mathrm{i}\left(\eta_{i}<0\right)$, while $\beta_{i}$ is the income elasticity of demand for exports and $Y_{A}$ is the national income of country A. The per capita coefficient for foreign demand of commodity i, expressed in (15), can be obtained by dividing both sides of (14) by $X_{\wedge}$, where we denote per capita income of country A by $y_{A}$ :

$$
a_{\hat{i n}}= \begin{cases}0 & \text { if } p_{\hat{i}}<p_{i} \\ \left(\frac{p_{i}}{p_{\hat{i}}}\right)^{\eta_{i}} y_{A}^{\beta_{i}} X_{\hat{i}}^{\beta_{i}-1} & \text { if } p_{\hat{i}} \geq p_{i}\end{cases}
$$


By the same reasoning for exports, if $p_{i}>p_{\hat{i}}$, we assume a standard import demand function and if country A has no comparative advantage in producing good $\mathrm{i}$, the per capita import demand for commodity $i$ in country $U$ is equal to zero. Likewise, the per capita import coefficient for commodity $i$ can be stated as:

$$
a_{\hat{i} n}= \begin{cases}0 & \text { if } p_{i}<p_{\hat{i}} \\ \left(\frac{p_{\hat{i}}}{p_{i}}\right)^{\psi_{i}} Y_{U}^{\phi_{i}} X_{n}^{\phi_{i}-1} & \text { if } p_{i} \geq p_{\hat{i}}\end{cases}
$$

where $\psi_{i}$ is the price elasticity of demand for imports of commodity $\mathrm{i}\left(\psi_{i}<0\right), \phi_{i}$ is the income elasticity of demand for imports and $Y_{U}$ is the real income of country U. Taking natural logarithms on both sides of equations (15) in the case of $p_{i}>p_{i}$, and differentiating them with respect to time, we obtain the growth rate of per capita export demand for commodity $i$ :

$$
\frac{\dot{a}_{\hat{i n}}}{a_{\hat{i n}}}= \begin{cases}0 & \text { if } p_{\hat{i}}<p_{i} \\ \eta_{i}\left(\sigma_{i}^{U}-\sigma_{i}^{A}\right)+\beta_{i} \sigma_{y}^{A}+\left(\beta_{i}-1\right) \hat{g} & \text { if } p_{\hat{i}} \geq p_{i}\end{cases}
$$

In (17) the following convention was adopted: $\frac{\dot{p}_{\hat{i}}}{p_{i}}=\sigma_{i}^{U}, \frac{\dot{p}_{i}}{p_{\hat{i}}}=\sigma_{i}^{A}, \frac{\dot{y}_{A}}{y_{A}}=\sigma_{y}^{A}$ and $\frac{\dot{X}_{\hat{n}}}{X_{\hat{n}}}=\hat{g}$. By adopting the same procedure with respect to equation (16) where $p_{i}>p_{\hat{i}}$ and by adopting the convention that $\frac{\dot{y_{U}}}{y_{U}}=\sigma_{y}^{U}$ and $\frac{\dot{X_{n}}}{X_{n}}=g$, we obtain its dynamic version:

$$
\frac{\dot{a_{\hat{i}}}}{a_{\hat{i}}}= \begin{cases}0 & \text { if } p_{i}<p_{\hat{i}} \\ \psi_{i}\left(\sigma_{i}^{A}-\sigma_{i}^{U}\right)+\phi_{i} \sigma_{y}^{U}+\left(\phi_{i}-1\right) g & \text { if } p_{i} \geq p_{\hat{i}}\end{cases}
$$

Let us assume that the rate of change of price of commodity $i$ is equal in both countries, that is $\sigma_{i}^{U}=\sigma_{i}^{A}$, and that $g=\hat{g}=0$, which means that the population in both countries remains constant. In this case, equations (17) and (18) can be respectively simplified to:

$$
\begin{aligned}
& \frac{\dot{a}_{\hat{i n}}}{a_{\hat{i n}}}=\beta_{i} \sigma_{y}^{A} \\
& \frac{\dot{a}_{\hat{i n}}}{\hat{a_{\hat{i n}}}}=\phi_{i} \sigma_{y}^{U}
\end{aligned}
$$

Indeed, only one of the two above equations is valid. In order for the equilibrium in the balance of payment to be maintained, it is necessary that the rate of change of equation (11) be equal to zero. Formally:

$$
\sum_{i=1}^{n-1}\left(\zeta \hat{a}_{i n}-\dot{a}_{\hat{i n}}\right) a_{n i}+\sum_{i=1}^{n-1}\left(\zeta a_{\hat{i n}}-a_{\hat{i n}}\right) \dot{a}_{n i}=0
$$

Considering the case in which there is no technical progress, that is $\dot{a}_{n i}(t)=0$, expression (21) becomes: 


$$
\sum_{i=1}^{n-1}\left(\zeta \dot{a}_{i n}-\dot{a}_{\hat{i n}}\right) a_{n i}=0
$$

By substituting equations (19) and (20) into equation (22) we obtain, after some algebraic manipulation:

$$
\sigma_{y}^{U}=\frac{\sum_{i=1}^{n-1} \xi \beta_{i} a_{i n} a_{n i}}{\sum_{i=1}^{n-1} \phi_{i} a_{\text {in }} a_{n i}} \sigma_{y}^{A}
$$

Equation (23) shows the relationship between the growth rate of per capita income in countries $U$ and $\mathrm{A}$. Let us define $\Delta$ as:

$$
\Delta=\frac{\sum_{i=1}^{n-1} \xi \beta_{i} a_{i n} a_{n i}}{\sum_{i=1}^{n-1} \phi_{i} a_{\text {in }} a_{n i}}
$$

A situation of uneven development will follow in the case of $\Delta<1$, which implies that per capita income of the advanced country grows at a higher rate than the per capita income of the underdeveloped one. It can be shown that $\Delta<1$ if and only if:

$$
\sum_{i=1}^{n-1}\left(\phi_{i} a_{i n}-\zeta \beta_{i} a_{i n}\right) a_{n i}<0
$$

This inequality holds if the share of consumer expenditures in A for $U$ goods is smaller than the share of consumer expenditures in $U$ for A goods, a phenomenon that could be explained by the so-called Engel's Law.

By summing over equation (19) and after some algebraic manipulation we obtain:

$$
\sigma_{y}^{A}=\frac{\sum_{i=1}^{n-1} \frac{\dot{a}_{i \hat{n}}}{a_{\hat{i n}}}}{\sum_{i=1}^{n-1} \beta_{i}}
$$

Substituting (26) in (23) we obtain:

$$
\sigma_{y}^{U}=\frac{\sum_{i=1}^{n-1} \xi \beta_{i} a_{i n} a_{n i}}{\left(\sum_{i=1}^{n-1} \phi_{i} a_{\hat{i n}} a_{n i}\right)\left(\sum_{i=1}^{n-1} \beta_{i}\right)} \sum_{i=1}^{n-1} \frac{\dot{a}_{i \hat{n}}}{a_{\hat{i n}}}
$$

Equation (27) can be seen as a multi-sectoral version of what Thirlwall (1979) called the balanceof-payments equilibrium growth rate, so that Araujo and Lima (2007) called it the Multi-Sectoral Thirlwall's Law. Equation (27) asserts that a country's growth rate of per capita income in country U is directly proportional to the growth rate of its exports, with such proportionality being inversely (directly) related to sectoral income elasticities of demand for imports (exports). These elasticities, in turn, are weighted by coefficients that measure the share of each sector in total exports and imports, respectively. Therefore, a major implication of the Multi-Sectoral Thirlwall's Law is that changes in the composition of demand or in the structure of production, which are not reflected in changes in income elasticities but come through changes in the share of each sector in aggregate exports or imports, also matter for growth. Given the income elasticites of exports and imports, Thirlwall's Law implies that a country's growth rate will rise only when the growth rate of world income increases, whereas the Multi-Sectoral Thirlwall's Law implies that a country can still raise its growth rate even when such a raise in growth of world income does not occur, provided it is able to change the sectoral composition of exports and/or imports accordingly. 


\section{Balance-of-payments-constrained growth: some empirical evidence}

There have been several tests of the BOPC growth approach using different econometric methodologies. For instance, Thirlwall (1979), Andersen (1993), McCombie (1997), Alonso and Garcimartín (1998-99) and Christopoulos and Tsionas (2003) have all found supporting evidence for samples of developed countries. Supporting evidence for samples of developing countries, in turn, was found, for instance, by Thirlwall and Hussain (1982), Bairam and Dempester (1991) and Perraton (2003). Previous results for countries of our sample are discussed in the next section in connection to our new results. But given the purpose of this paper, we briefly review here some contributions that have investigated empirically issues related to structural change in a BOPC growth framework. Alonso \& Garcimartín (1998-99) adopted an export function including a technological index intended to capture structural changes in exports, which yielded a good fit. In an empirical exercise for the Spanish economy which found support for the original Thirlwall's Law, the authors also found that the worsening of relative prices was offset by the improvement of technology, which maintained the country's overall competitiveness level.

Dutt (2003) incorporates a BOPC growth framework into a fully-specified model of North-South trade to show how it can explain uneven development. Using OECD to represent the North and nonOECD the South, Dutt (2003) estimated the import and export functions including an interaction term between trend and south income to capture changes in these elasticities. The results showed that these elasticities are different and, indeed, such difference between had been growing, which implied uneven development between the two groups of countries. Pacheco-López and Thirlwall (2006) applied the BOPC growth model to seventeen Latin American countries over the period 1977-2002. The rolling regression technique was used to analyze the evolution of income elasticity of imports of Latin America as a whole, as well as of individual countries. As a result of trade liberalization, a trend increase is found for Latin America as a whole and for some individual countries, and the balance-of-payments equilibrium growth rate is a good predictor of the growth performance in nine out of those seventeen countries. Cimoli, Porcile and Rovira (2009) analyze why Latin America failed to achieve a sustainable convergence with the developed world since 1960. First, it is shown, by employing rolling regressions, that there are critical differences between Latin America, the developed countries and Asian countries as regards the evolution of the income elasticity of the demand for imports, the rate of growth of exports and, therefore, the BOPC growth rate. The income elasticity of the demand for imports in Latin America showed an upward trend, which was not matched by a similar increase in exports, as it seems to have occurred in the case of east Asian countries. Second, using a broad sample of developed and developing economies, the authors show that developing countries that succeed in reducing the income gap were those that transformed their production structures in favor of sectors which are more technology-intensive and whose international demand grows at higher rates.

\subsection{Data description}

As intimated earlier, this paper contributes to the BOPC growth approach by testing both the original and a multi-sectoral version of Thirlwall's Law for a sample of Latin American (Argentina, Brazil, Colombia and Mexico) and Asian (South Korea, Malaysia, Philippines and Singapore) countries over the period 1962-2006 (except for Malaysia, where data is available only after 1964). Trade data come from the United Nations Commodity Trade Statistics Database (COMTRADE). As far as the MultiSectoral Thirlwall's Law is concerned, the choice of the level of sectoral aggregation should be based upon both theoretical and empirical considerations. Arguably, this choice should allow not only the capturing of some theoretically relevant impacts of structural change on the extent of the balance-ofpayments constraint, but also the meeting of technical requirements regarding sample size, homogeneity of data series and the number of parameters to be estimated. As changes in the sectoral income elasticities of exports and imports have a significant technological dimension to them, we used Lall's (2000) technological classification. Lall (2000) classified trade data at three-digit SITC (Standard International 
Trade Classification) revision 2 by their technological intensity. As SITC rev.2 data were available only after the 1980s, Lall's classification was adapted to data at three-digit SITC rev. 1, since at this revision, data were available after 1962. The scheme used to categorize products by technology was based on a combination of Pavitt (1984) and OECD (1994) classifications, which were extended to take into account product groups or cluster of particular interest for developing countries. This scheme is shown in Appendix 1. ${ }^{1}$ The other variables used in the estimations are individual gross domestic product $(g d p)$, world gross domestic product $(g d p w)$ and individual real exchange rate. The $g d p$ series come from the World Development Indicators (WDI) and real exchange rates were constructed using data from International Financial Statistics IMF. ${ }^{2}$ Given the inexistence of sectoral price indexes for the whole time span, we used the aggregate real exchange rate (rer) as a proxy for the sectoral real exchange rates.

\section{Empirical Results}

The following equations were estimated:

$$
\begin{gathered}
\ln M_{t}=\pi \ln g d p_{t}+\psi \ln \text { rer }_{t} \\
\ln M_{i t}=\pi_{i} \ln g d p_{t}+\psi_{i} \ln r e r_{t} \\
\ln X_{i t}=\beta_{i} \ln g d p w_{t}+\eta_{i} \ln r e r_{t}
\end{gathered}
$$

where $\pi_{i}, \psi_{i}, \beta_{i}$ e $\eta_{i}$ are the parameters to be estimated, $i=1,2, \ldots, 6$ refers to sectors and the other variables were defined above.

As the series used in the estimations can be generated by a non-stationary process, OLS regression could be spurious. Since Dickey and Fuller's (1979) paper, many tests have been developed to determine if a series is I(1) or I(0). Because of the low power of the ADF test, we also tested if the series have a unit root using the KPSS test. All series used in the paper are integrated of order one, so that we used Johansen's (1995) methodology to test if the series are cointegrated, that is, if at least one cointegration vector exists. ${ }^{3}$ When the null hypothesis of cointegration was not rejected, we estimated a vector error correction to obtain the income and price elasticities. In the case of rejection, which happened only for Argentina's imports of sector others, these elasticities were obtained by OLS in first differences.

Table 1 presents the results for the imports function, equation (28), for the whole sample. Note that the real exchange rate is significant only for the Latin American countries. This is not a surprising result, since the low or no significance of the real exchange rate has been recurrently found in similar exercises (e.g. Andersen, 1993). The results for the sectoral imports functions are presented in Appendices 4 and 5, with the income variables being significant at 5\% for all sectors and for all countries. Note that the real exchange rate seems to play a major role in determining sectoral imports in some countries. Indeed, for all Brazilian sectors the real exchange rate is significant at $5 \%$ and the relation has the expected sign. For Argentina, Mexico, Philippines and Singapore, in at least three sectors the terms of trade are significant. Moreover, there is no case of real exchange rate being significant but with the relation not having the expected sign. When the values of income elasticities are compared between sectors of the same country, the technology-intensive sectors have higher income elasticities than the resource-based sectors. For imports, however, these differences are much lower than for exports.

\footnotetext{
${ }^{1}$ We refer to each group as follows: prim (primary products), rrnn (resource-based manufactures), ltech (low-technology manufactures), mtech (medium-technology manufactures), htech (high-technology manufactures) and others (other transactions). Meanwhile, $x$ was used to refer to exports and $m$ to imports.

${ }^{2}$ Real exchange rates are defined as the product between official exchange rate period average (national currency/US dollar) and the ratio of USA whole sale price index (WPI) and countries' consumer price index (CPI). In the cases of Brazil and Korea, WPI was used instead of CPI because of data availability.

${ }^{3}$ The results of unit root tests, as well as the cointegration tests, are available from the authors on request.
} 
Table 1: Estimated imports functions (1962-2006)

\begin{tabular}{|c|c|c|c|c|c|c|c|c|}
\hline & Argentina & Brazil & Colombia & Mexico & Korea & Philippines & Malaysia* & Singapore \\
\hline & LIMP & LIMP & LIMP & LIMP & LIMP & LIMP & LIMP & LIMP \\
\hline LRER & $\begin{array}{c}\mathbf{- 0 . 8 3 9} \\
{[-7.629]}\end{array}$ & $\begin{array}{c}\mathbf{- 2 . 5 3 8 7} \\
{[-3.286]}\end{array}$ & $\begin{array}{c}\mathbf{- 1 . 5 2 7} \\
{[-11.144]}\end{array}$ & $\begin{array}{c}\mathbf{- 1 . 8 4 5} \\
{[-2.605]}\end{array}$ & $\begin{array}{c}-0.691 \\
{[-0.979]}\end{array}$ & $\begin{array}{c}-1.070 \\
{[-1.791]}\end{array}$ & $\begin{array}{c}0.579 \\
{[1.659]}\end{array}$ & $\begin{array}{c}0.764 \\
{[1.616]}\end{array}$ \\
\hline LGDP & $\begin{array}{c}\mathbf{1 . 7 2 6} \\
{[10.311]}\end{array}$ & $\begin{array}{c}1.610 \\
{[6.014]}\end{array}$ & $\begin{array}{c}\mathbf{1 . 6 6 7} \\
{[29.879]} \\
\end{array}$ & $\begin{array}{c}\mathbf{2 . 8 2 1} \\
{[8.631]}\end{array}$ & $\begin{array}{c}1.209 \\
{[6.454]}\end{array}$ & $\begin{array}{c}\mathbf{2 . 0 7 3} \\
{[12.991]}\end{array}$ & $\begin{array}{c}\mathbf{1 . 3 3 9} \\
{[17.351]}\end{array}$ & $\begin{array}{c}\mathbf{1 . 3 3 3} \\
{[17.868]}\end{array}$ \\
\hline $\begin{array}{l}\text { Cointegration } \\
\text { Specification }\end{array}$ & 2 & 2 & 2 & 2 & 1 & 2 & 2 & 3 \\
\hline Lag Structure & 0 & 0 & 1 & 1 & 0 & 0 & 0 & 1 \\
\hline
\end{tabular}

Meanwhile, Appendices 2 and 3 show the results for the sectoral export functions. Note that in both regions the world income is the most important variable determining sectoral exports. Indeed, it was only for the sector others in the Brazilian and Philippine cases that this variable was not significant at 5\% in a t-test. However, for some countries and sectors the real exchange rate is not significant and for some sectors - Argentina's htech and other; Mexico's ltech, htech and others and Malaysia's ltech and mtech it is significant but the relation has the wrong (i.e. negative) sign. When we compare the values of income elasticities of exports among sectors of the same country, we realize that the results support Engel's Law, since sectors with higher levels of technology have higher elasticities. In some cases, however, low or medium-technology sectors have a higher elasticity than sectors with higher levels of technology. But there is no case in which the income elasticities are higher for resource-based sectors than technologyintensive sectors. Comparing the sectoral income elasticities of exports among the sample countries, it is noted that, in technology-intensive sectors, income elasticities in Asian countries are higher than in Latin American countries (except for Mexico).

Having estimated the income elasticities of imports, both aggregate and sectoral, and the sectoral income elasticities of exports, we then calculated the BOPC growth rate, for each country, according to the original Thirlwall's Law, equation (8'), and the Multi-Sectoral Thirlwall's Law, equation (27). Then, in order to test the validity of these models, we compared the actual rates of growth with the predicted ones. This comparison was conducted by calculating the t-statistics for the null hypothesis that the actual growth rates are equal to those predicted by the model. The results reported in Table 2 show that only in the case of South Korea it is possible to reject the equality between the growth rate given by Thirlwall's Law and the actual growth rate. These results confirm previous studies including (sometimes among others) some of our sample countries. López and Cruz (2000) and Holland, Vieira and Canuto (2004) also found supporting empirical evidence for the original Thirlwall's Law for the same Latin American countries for the periods 1965-1996 and 1950-2000, respectively. Bértola, Higachi and Porcile (2002) found that the original TL is a good predictor of the Brazilian growth experience in the 1890-1973 period, while Carvalho and Lima (2009) found supporting evidence for an extended (to include capital flows and terms of trade) version of Thirlwall's Law using Brazil data for the 1930-2004 period. Meanwhile, Hussain (1999), using data from 1970 to 1990, found supporting evidence for an extended (to include capital flows) version of Thirlwall's Law for Malaysia, and for both such an extended and the original version of Thirlwall's Law for South Korea and Philippines. While Ansari, Hashemzadeh and Xi (2000) found that the original Thirlwall's Law is a good predictor of growth in Malaysia and Philippines in the 1970-1996 period, Perraton (2003), using data for the 1973-1995 period, found evidence for Thirlwall's Law for Argentina, Brazil, South Korea, Malaysia and Philippines.

Meanwhile, for all countries in our sample the growth rate corresponding to the Multi-Sectoral Thirlwall's Law seems to be a good predictor of the growth rate of per capita income, since in all the cases the equality of those rates is not rejected. Though for some countries the multi-sectoral version presents a higher absolute error than the aggregate version, for both groups of countries the absolute mean 
error is lower for the multi-sectoral model, implying that, at least in a mean sense, the latter model fits better than the original, aggregate model.

Table 2: Estimated original and multi-sectoral Thirlwall's Law (1962-2006)

\begin{tabular}{lcccccc}
\hline Country & $\begin{array}{c}\text { Income Growth } \\
\text { Rate (1) }\end{array}$ & $\begin{array}{c}\text { TL } \\
(2)\end{array}$ & $\begin{array}{c}\text { Absolute } \\
\text { Error }|1-2|\end{array}$ & $\begin{array}{c}\text { Per capita Income } \\
\text { Growth Rate(3) }\end{array}$ & $\begin{array}{c}\text { MSTL } \\
(4)\end{array}$ & $\begin{array}{c}\text { Absolute } \\
\text { Error|3-4| }\end{array}$ \\
\hline Argentina & 2.70 & 3.24 & 0.54 & 1.30 & 1.16 & 0.13 \\
Brazil & 4.33 & 4.83 & 0.50 & 2.22 & 1.94 & 0.28 \\
Colombia & 4.14 & 3.66 & 0.48 & 1.95 & 1.92 & 0.03 \\
Mexico & 4.38 & 3.78 & 0.60 & 2.09 & 2.51 & 0.42 \\
Mean & $\mathbf{3 . 8 9}$ & $\mathbf{3 . 8 8}$ & $\mathbf{0 . 5 3}$ & $\mathbf{1 . 8 9}$ & $\mathbf{1 . 8 8}$ & $\mathbf{0 . 2 2}$ \\
Singapore & 8.01 & 7.46 & 0.55 & 5.81 & 3.14 & 2.67 \\
Malaysia $^{\text {a }}$ & 6.59 & 6.81 & 0.22 & 3.95 & 3.59 & 0.36 \\
Korea & 7.40 & $15.26^{\dagger}$ & 7.86 & 5.93 & 2.80 & 3.13 \\
Philippines & 3.97 & 3.67 & 0.30 & 1.41 & 2.25 & 0.84 \\
Mean & $\mathbf{6 . 4 9}$ & $\mathbf{8 . 3 0}$ & $\mathbf{2 . 2 3}$ & $\mathbf{4 . 2 7}$ & $\mathbf{2 . 9 4}$ & $\mathbf{1 . 7 5}$ \\
\hline
\end{tabular}

$\dagger:$ Rejects the equality between actual and predicted income growth rates at $5 \%$ significance.

${ }^{\mathrm{a}}$ : over the period $1964-2006$.

The above results having revealed that the multi-sectoral version is valid for all countries, we then used the multi-sectoral approach to BOPC growth develop a new methodology to analyze the evolution of the trade income elasticities. While the previous research adopted the rolling regressions technique, this new methodology consists in using the estimated sectoral income elasticities and weighting them by the yearly share of each sector in total imports and exports. Hence this alternative methodology makes it possible to capture the impact of structural change, identified here with change in the sectoral composition of exports and imports, on the change in the aggregate elasticities. Figure 1 shows the evolution of the ratio of the weighted income elasticity of exports to the weighted income elasticity of imports, which yields, according to the multi-sectoral model, and for a given growth rate of the world income, the growth rate corresponding to the Multi-Sectoral Thirlwall's Law. Note that the Latin American countries, except Mexico, have not changed the composition of their exports and imports in a way leading to higher BOPC growth rates. The Asian countries, in turn, have managed to change the composition of their exports and imports in a way that led their weighted income elasticity of exports to grow faster than their weighted income elasticity of imports.

Figure 1: Evolution of the ratio of the weighted income elasticities of exports to the weighted income elasticities of imports

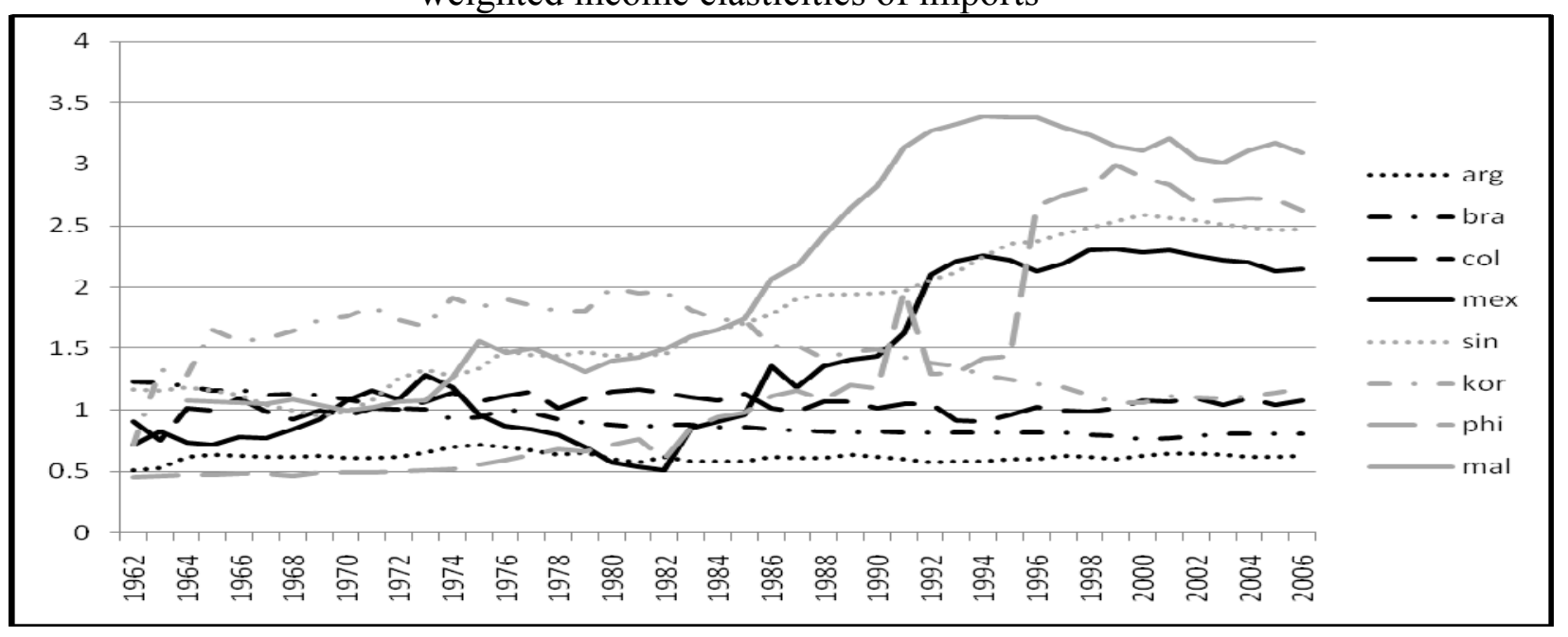


As regards individual countries (Figures 2 and 3), the evolution of the weighted trade income elasticities is more diverse for Latin American countries than for Asian countries. Except for a few years in the late 1970s and early 1980s, Argentina's income elasticity of exports increased slowly over the period. However, the corresponding ratio of trade income elasticities has remained relatively stable. In the Brazilian case, meanwhile, the weighted elasticity of imports grew more than the weighted elasticity of exports over the period, which made for a fall in the ratio of trade income elasticities. The experience of Colombia is marked by phases in which the income elasticity of exports grew faster than the income elasticity of imports and phases in which the reverse was the case. The evolution of income elasticities in the Mexican case, in turn, is similar to that of Asian countries, which have managed to raise the ratio of the weighted income elasticity of exports to the weighted income elasticity of imports. However, the Mexican figures may be inflated by exports of labor-intensive goods with very little value added (the maquila scheme) to the United States, a feature which is not captured by trade data. Besides, there seems to have occurred a structural break in Philippines' composition of exports and imports of high-technology products in 1995 .

Figure 2: Evolution of the weighted income elasticity of imports

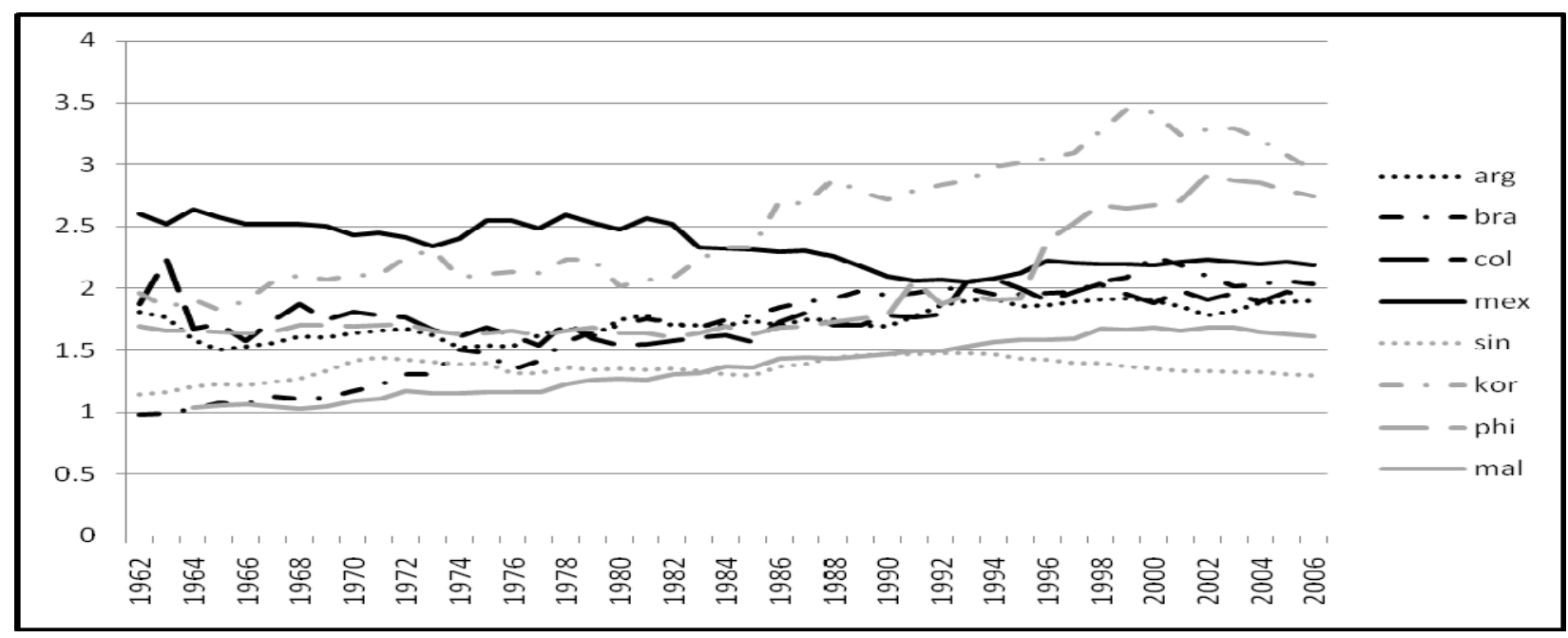

Figure 3: Evolution of the weighted income elasticity of exports

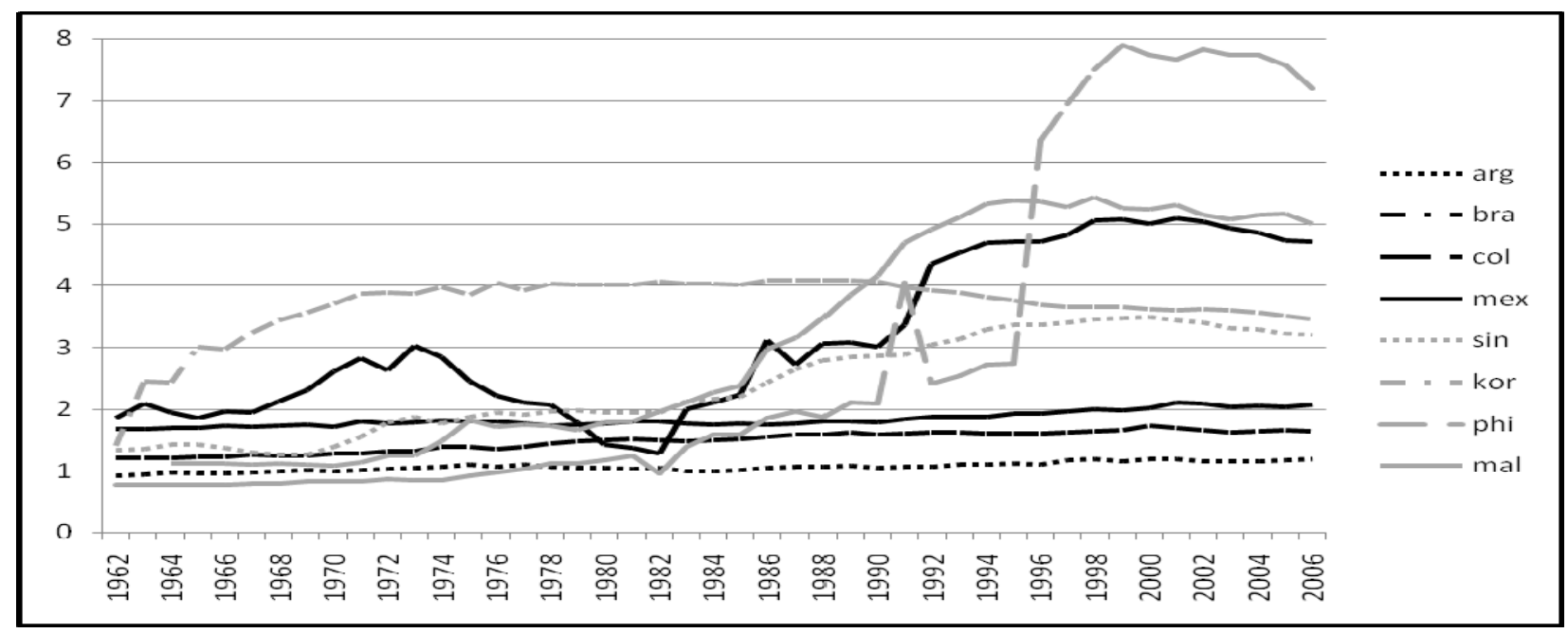

\section{Concluding remarks}

The paper contributed to the empirical literature on BOPC growth by investigating how structural change, identified with change in the sectoral composition of exports and/or imports, affects the extent of 
the external constraint. This has been done by testing both the original and a multi-sectoral version of Thirlwall's Law for a sample of Latin American and Asian countries over the period 1962-2006. While the original Thirlwall's Law was found to hold for all sample countries but South Korea, the MultiSectoral Thirlwall's Law was found to hold for all of them. Though for some countries the multi-sectoral version of Thirlwall's Law presented a higher absolute error than the aggregate version, for both groups of countries the absolute mean error was lower for the multi-sectoral version, implying that, at least in a mean sense, the multi-sectoral model fits better than the aggregate model.

Moreover, we used the multi-sectoral approach to BOPC growth to develop an alternative methodology to analyze the evolution of income elasticities of exports and imports. This alternative methodology makes it possible to capture the impact of structural change, identified with change in the sectoral composition of the international trade, on a change in the aggregate income elasticities. We then found that, unlike the sample of Latin American countries (except Mexico), the sample of Asian countries has managed to change the composition of their exports and imports in a way that led their weighted income elasticity of exports to grow faster than their weighted income elasticity of imports.

\section{References}

Alonso, J.A., and Garcimartín, C. "A new approach to balance-of-payments constraint: some empirical evidence." Journal of Post Keynesian Economics, Winter, 1998-99, 21(2), 259-282.

Andersen, P.S. "The 45 rule". Applied Economics, 1993, Vol. 25, 1279-1284.

Ansari, H., Hashemzadeh, N., and Xi, Y. "The chronicle of economic growth in southeast asian countries: does Thirlwall's Law provide an adequate explanation". Journal of Post Keynesian Economics, 2000, 22(4).

Araujo, R. A., and Lima, G. T. "A structural economic dynamics approach to balance-of-paymentsconstrained growth". Cambridge Journal of Economics, 2007, 31(5), 755-774.

Barbosa-Filho, N. "The balance-of-payments constraint: from balanced trade to sustainable debt". Banca Nazionale del Lavoro Quarterly Review, 2001, 54(219), 381-400.

Bairam, E. "Levels of economic development and appropriate specification of the Harrod foreing-trade multipler". Journal of Post Keynesian Economics, 1997, 19(3), 337-344.

Bairam, E., and Dempester,G. J. "The Harrod foreign trade multiplier and economic growth in Asian countries". Applied Economics, 1991, Vol. 23, 1719-1724.

Bértola, L., Higachi, H., and Porcile, G. "Balance-of-payments-constrained growth in Brazil: a test of Thirlwall's Law, 1890-1973". Journal of Post Keynesian Economics, 2002, 25(1), 123-140.

Carvalho, V. R., and Lima, G. T. "Estrutura produtiva, restrição externa e crescimento econômico: a experiência brasileira". Economia e Sociedade, 2009, 18(1), 31-60.

Cimoli, M.; Porcile, G.; and Rovira, S. "Structural Change and the BOP-Constraint: Why did Latin America fail to converge?" Cambridge Journal of Economics, 2009, forthcoming.

Christopoulos, D., and Tsionas, E. "A reassessment of balance of payments constrained growth: results from panel unit root and panel cointegration tests". International Economic Journal, 2003, 17(3).

Dickey, D. A., and Fuller, W. A. "Distribution of the estimators for autoregressive time series with a unit root". Journal of the American Statistical Association, 1979, 74(366), 427-41.

Dutt, A. K. "Income elasticities of imports, North-South trade and uneven development". In A. K. Dutt and J. Ros (eds.), Development economics and structuralist macroeconomics. Cheltenham, UK; Northampton, MA: Edward Elgar, 2003, pp. 307-335.

Holland, M., Vieira, F., and Canuto, O. "Economic growth and the balance-of-payments constraint in Latin America". Investigación Económica, 2004, Vol. LXIII, 247.

Hussain, M. N. "The balance-of-payments constraint and growth rate differences among African and East Asian economies". African Development Review, 1999, June.

Johansen, S. "Likelihood based inference in cointegrated vector auto-regressive models". Oxford: Oxford University Press, 1995.

Lall, S. "The technological structure and performance of developing country manufactured exports, 1985 98". Oxford Development Studies, 2000, 28(3). 
López, J., and Cruz, A. "Thirlwall's Law and beyond: the Latin American Experience", 2000, Journal of Post Keynesian Economics, 22(3).

McCombie, J. S. L. "On the empirics of balance-of-payments-constrained growth". Journal of Post Keynesian Economics, 1997, 19(3), 345-375.

McCombie, J. S. L., and Roberts, M. "The role of balance of payments in economic growth". In: M. Setterfield (ed.), The economics of demand-led growth. Cheltenham, UK; Northampton, MA: Edward Elgar, 2002, pp. 87-114.

McCombie, J. S. L., and Thirlwall, A. P. "Economic growth and balance-of-payments constraint revisited" In P. Arestis, G. Palma, and M. Sawyer (eds.) Markets, Unemployment and Economic Policy, Vol. II, London: Routledge, 1997.

Moreno-Brid, J. C. "On capital flows and the balance-of-payments constrained growth model". Journal of Post Keynesian Economics, 1998-99, 21(2), 283-298.

OECD. "Globalization and Competitiveness: Relevant Indicators", Paris, 1994, OECD Directorate for Science, Technology and Industry, DSTI/EAS/IND/WP9(94)1.

Pacheco-López, P., and Thirlwall, A. P. "Trade liberalization, the income elasticity of imports and economic growth in Latin America". Journal of Post Keynesian Economics, 2006, 29(1), 41-66.

Palley, T. I. "Pitfalls in the theory of growth". In: M. Setterfield (ed.), The economics of demand-led growth. Cheltenham, UK; Northampton, MA: Edward Elgar, 2002, pp. 115-125.

Pasinetti, L. Structural change and economic growth. Cambridge, Cambridge University Press, 1981. . Structural economic dynamics. Cambridge, Cambridge University Press, 1993.

Pavitt, K. "Sectoral patterns of technical change: towards a taxonomy and a theory" Research Policy, 1984, Vol. 13, 343-373.

Perraton, J. "Balance of payments constrained growth and developing countries: an examination of Thirlwall's hypothesis". International Review of Applied Economics, 2003, Vol. 117.

Setterfield, M. "'History versus equilibrium' and the theory of economic growth". Cambridge Journal of Economics, 1997, 21(3), 365-378.

. Supply and demand in the theory of long-run growth: introduction to a

symposium on demand-led growth. Review of Political Economy, 2003, 15(1), 23-32.

Thirlwall, A. P. "The balance of payments constraint as an explanation of international growth rate differences”. Banca Nazionale del Lavoro Quarterly Review, 1979, Vol. 128, 45-53.

Reflections on the concept of balance-of-payments-constrained growth. Journal

of Post Keynesian Economics, 1997, 19(3), 377-384.

. The nature of economic growth. Cheltenham, UK, Edward Elgar, 2002.

Thirlwall, A. P. and Hussain, M. N. "The balance of payments constraint, capital flows and growth rate differences between developing countries". Oxford Economic Papers, 1982, 34(3), 498-510. 


\section{Appendix 1: Technological classification}

\section{Classification}

\section{Primary Products}

\section{Manufactured Products}

Resource-based manufactures

Agro/forest-based products

Other resource-based products

Low-Technology manufactures

Textile/fashion cluster

Other low technology

Medium Technology manufactures

Automotive products

Medium technology process industries

Medium technology engineering industries

High-Technology manufactures

Eletronics and electrical products

Other high technology

Other transactions

Source: Lall (2000, p. 341)

\section{Examples}

Fresh fruit, meal, rice, cocoa, tea, coffee, wood, coal, crude, petroleum, gas

Prepared meats/fruits, beverages, wood products, vegetable, oils

Ore concentrates, petroleum/rubber products, cement, cut gems, glass

Textile fabrics, clothing, headgear, footwear, leather manufactures, travel goods

Pottery, simple metal parts/structures, furniture, jewellery, toys, plastic products

Passenger vehicles and parts, commercial vehicles, motorcycles and parts

Synthetic fibres, chemicals and paints, fertilizers, plastics, iron, pipes/tubes

Engines, motors, industrial machinery, pumps, switchgear, ships, watches

Office/data processing/telecommunications equip, TVs, transistors, turbines, power-generating equipment

Pharmaceuticals, aerospace, optical/measuring instruments, cameras Electricity, cinema film, printed matter, "special" transactions, gold, art, pets 
Appendix 2: Estimation Results of the Sectoral Export Functions for the Latin American Countries - 1962-2006

\begin{tabular}{|c|c|c|c|c|c|c|c|c|c|c|c|c|}
\hline & Argentina & & & & & & Brazil & & & & & \\
\hline \multirow{3}{*}{ LRER } & LXPRIM & LXRRNN & LXLTECH & LXMTECH & LXHTECH & LXOTHERS & LXPRIM & LXRRNN & LXLTECH & LXMTECH & LXHTECH & LXOTHERS \\
\hline & 0.427049 & 0.593681 & 0.335837 & 0.021265 & -0.927099 & -3.683756 & 1.165949 & -0.104101 & 0.709544 & 0.163943 & 0.588126 & -1.06085 \\
\hline & [1.86988] & [2.28424] & [1.06880] & {$[0.07363]$} & [ -5.09239] & [ -4.45927] & [3.82885] & [ -0.21968$]$ & {$[0.65351]$} & [0.18011] & {$[1.20470]$} & [ -0.98361$]$ \\
\hline \multirow[t]{2}{*}{ LGDPW } & 0.944353 & 0.774089 & 1.216029 & 1.921035 & 1.608315 & 4.151277 & 1.147853 & 1.357788 & 1.539454 & 2.167484 & 2.964311 & 0.649981 \\
\hline & [3.95336] & {$[135.782]$} & [3.99699] & {$[6.86934]$} & [8.99897] & {$[4.66315]$} & [5.94328] & {$[6.35641]$} & [3.14538] & [5.28240] & {$[13.4700]$} & {$[1.33692]$} \\
\hline $\begin{array}{l}\text { Cointegration } \\
\text { Specification }\end{array}$ & 2 & 1 & 3 & 3 & 3 & 2 & 2 & 2 & 3 & 3 & 3 & 3 \\
\hline \multirow[t]{2}{*}{ Lag Structure } & 3 & 0 & 0 & 0 & 1 & 4 & 4 & 0 & 0 & 0 & 0 & 0 \\
\hline & Colombia & & & & & & Mexico & & & & & \\
\hline \multirow{3}{*}{ LRER } & LXPRIM & LXRRNN & LXLTECH & LXMTECH & LXHTECH & LXOTHERS & LXPRIM & LXRRNN & LXLTECH & LXMTECH & LXHTECH & LXOTHERS \\
\hline & -0.097032 & -0.23939 & -0.172586 & -0.138908 & 0.017934 & 0.605711 & 0.343696 & 0.337699 & -2.24526 & -1.351747 & -2.786732 & -1.968035 \\
\hline & [ -0.29195$]$ & {$[-0.47673]$} & {$[-0.38960]$} & {$[-0.23991]$} & {$[0.00601]$} & [0.36679] & {$[0.37441]$} & [0.64059] & {$[-2.96556]$} & [ -1.86819] & {$[-2.47515]$} & [ -5.71079] \\
\hline \multirow[t]{2}{*}{ LGDPW } & 1.659599 & 1.702817 & 1.911182 & 3.065165 & 7.167234 & 0.604656 & 0.823804 & 2.768664 & 4.467422 & 5.874663 & 6.499657 & 2.083062 \\
\hline & [11.7302] & [7.07817] & [10.1351] & {$[12.4363]$} & [5.64212] & {$[0.76821]$} & [11.4536] & [9.62335] & [13.0991] & {$[18.0240]$} & [12.8157] & [13.4187] \\
\hline $\begin{array}{l}\text { Cointegration } \\
\text { Specification }\end{array}$ & 3 & 2 & 3 & 3 & 2 & 2 & 0 & 2 & 2 & 3 & 2 & 3 \\
\hline Lag Structure & 0 & 1 & 0 & 0 & 0 & 1 & 2 & 2 & 0 & 0 & 0 & 0 \\
\hline
\end{tabular}

[ ]: t-Statistic: significant parameters are in bold. 
Appendix 3: Estimation Results of the Sectoral Export Functions for the Asian Countries - 1962-2006

\begin{tabular}{|c|c|c|c|c|c|c|c|c|c|c|c|c|}
\hline & Korea & & & & & & Malaysia* & & & & & \\
\hline \multirow{3}{*}{ LRER } & LXPRIM & LXRRNN & LXLTECH & LXMTECH & LXHTECH & LXOTHERS & LXPRIM & LXRRNN & LXLTECH & LXMTECH & LXHTECH & LXOTHERS \\
\hline & -0.434005 & 1.243315 & -0.35383 & 0.275115 & 1.053511 & -0.134547 & 0.147053 & 0.794711 & -8.513661 & -8.165939 & 1.318252 & 6.39339 \\
\hline & {$[-0.44108]$} & [1.46508] & {$[-0.40123]$} & {$[0.17746]$} & {$[0.42781]$} & [ -0.13089] & [0.36329] & [1.74860] & [ -4.90955] & {$[-2.04216]$} & {$[1.05754]$} & [4.04894] \\
\hline \multirow[t]{2}{*}{ LGDPW } & 0.853851 & 2.569779 & 5.519924 & 3.439071 & 3.878824 & 2.918163 & 0.773418 & 0.762406 & 8.456117 & 12.22451 & 4.538798 & 0.565301 \\
\hline & [3.87267] & [9.03816] & {$[2.79077]$} & [6.62122] & {$[4.06502]$} & [8.47339] & [55.7794] & [48.9713] & [10.9011] & [6.83423] & [8.13981] & {$[10.4511]$} \\
\hline $\begin{array}{l}\text { Cointegration } \\
\text { Specification }\end{array}$ & 1 & 3 & 4 & 2 & 2 & 2 & 1 & 1 & 3 & 2 & 2 & 1 \\
\hline \multirow[t]{2}{*}{ Lag Structure } & 0 & 0 & 0 & 0 & 1 & 0 & 0 & 0 & 0 & 0 & 0 & 0 \\
\hline & \multicolumn{6}{|l|}{ Singapore } & \multicolumn{6}{|l|}{ Philippines } \\
\hline \multirow{3}{*}{ LRER } & LXPRIM & LXRRNN & LXLTECH & LXMTECH & LXHTECH & LXOTHERS & LXPRIM & LXRRNN & LXLTECH & LXMTECH & LXHTECH & LXOTHERS \\
\hline & 15.86775 & 0.379621 & 1.037254 & 1.372206 & -2.02249 & 4.347048 & 1.508905 & 0.891896 & 0.316042 & 0.691796 & 3.203266 & -6.508213 \\
\hline & [3.91498] & {$[0.44662]$} & [1.38045] & [1.64713] & [- 1.92570$]$ & [2.19662] & [ 0.91541$]$ & [ 0.83186$]$ & [ 0.34335$]$ & [ 1.39991$]$ & [ 1.68999$]$ & {$[-1.23538]$} \\
\hline \multirow[t]{2}{*}{ LGDPW } & 0.736252 & 0.823767 & 2.349053 & 3.746405 & 4.317977 & 0.771536 & 0.757177 & 0.737922 & 2.850631 & 4.80719 & 10.07305 & 0.200433 \\
\hline & [8.22307] & {$[43.8720]$} & {$[6.77538]$} & {$[12.1121]$} & [11.0376] & {$[17.6486]$} & {$[3.74825]$} & [5.61595] & [11.0082] & [34.5779] & [18.8903] & {$[0.31044]$} \\
\hline $\begin{array}{l}\text { Cointegration } \\
\text { Specification }\end{array}$ & 1 & 1 & 2 & 3 & 2 & 1 & 1 & 1 & 2 & 3 & 2 & 1 \\
\hline Lag Structure & 0 & 0 & 5 & 1 & 1 & 0 & 0 & 0 & 0 & 0 & 0 & 0 \\
\hline
\end{tabular}


Appendix 4: Results of the Sectoral Import Functions for the Latin American Countries - 1962-2006

\begin{tabular}{|c|c|c|c|c|c|c|c|c|c|c|c|c|}
\hline & Argentina & & & & & & Brazil & & & & & \\
\hline \multirow{3}{*}{ LRER } & LMPRIM & LMRRNN & LMLTECH & LMMTECH & LMHTECH & LMOTHERS* & LMPRIM & LMRRNN & LMLTECH & LMMTECH & LMHTECH & LMOTHERS \\
\hline & 0.561964 & -0.807153 & -1.529054 & -0.810206 & -0.84553 & -0.259458 & 2.65715 & -2.241333 & -3.332099 & -2.751086 & -2.622151 & -2.595675 \\
\hline & [0.58553] & {$[-7.41481]$} & {$[-6.34381]$} & {$[-5.43351]$} & [ -4.28745] & {$[-1.077858]$} & [2.84837] & {$[-5.87704]$} & {$[-4.26514]$} & [ -5.95509] & [ -4.75307] & {$[-4.60736]$} \\
\hline \multirow[t]{2}{*}{ LGDP } & 0.844492 & 0.987961 & 1.420847 & 2.077562 & 2.819966 & 1.677098 & 0.698722 & 1.248145 & 1.283857 & 1.341587 & 1.809218 & 0.478868 \\
\hline & {$[-34.1330]$} & {$[-5.96684]$} & {$[-3.87557]$} & {$[-9.16010]$} & {$[-9.40101]$} & 2.071621 & [2.16043] & {$[9.44000]$} & {$[4.74010]$} & [8.37641] & [9.45938] & {$[2.45173]$} \\
\hline $\begin{array}{l}\text { Cointegration } \\
\text { Specification }\end{array}$ & 1 & 3 & 3 & 3 & 2 & - & 2 & 2 & 2 & 2 & 2 & 3 \\
\hline \multirow[t]{3}{*}{ Lag Structure } & 0 & 0 & 0 & 0 & 0 & - & 0 & 0 & 0 & 0 & 0 & 0 \\
\hline & Colombia & & & & & & Mexico & & & & & \\
\hline & LMPRIM & LMRRNN & LMLTECH & LMMTECH & LMHTECH & LMOTHERS & LMPRIM & LMRRNN & LMLTECH & LMMTECH & LMHTECH & LMOTHERS \\
\hline \multirow[t]{2}{*}{ LRER } & 1.173109 & 0.769648 & -3.173199 & -1.383941 & -4.841817 & -7.947296 & -0.374503 & -2.777978 & -6.394764 & 0.11404 & -3.732845 & -3.633168 \\
\hline & [1.45397] & [1.61444] & {$[-5.57391]$} & [ -9.60988] & [-3.69012] & {$[-2.87714]$} & {$[-1.86980]$} & {$[-14.7702]$} & [- 13.4895] & {$[0.12188]$} & {$[-6.38915]$} & [ - 2.74739$]$ \\
\hline \multirow[t]{2}{*}{ LGDP } & 0.535326 & 0.663954 & 2.58239 & 1.466219 & 3.863651 & 5.554176 & 2.129734 & 1.352663 & 1.145078 & 3.63939 & 1.245592 & 1.214371 \\
\hline & [2.15924] & [4.53244] & [11.1132] & {$[24.9050]$} & [8.37372] & {$[5.71807]$} & {$[23.6958]$} & [14.9355] & [5.03047] & {$[10.3625]$} & [22.1461] & {$[9.53902]$} \\
\hline $\begin{array}{l}\text { Cointegration } \\
\text { Specification }\end{array}$ & 1 & 1 & 2 & 3 & 3 & 2 & 2 & 3 & 3 & 2 & 1 & 1 \\
\hline Lag Structure & 0 & 0 & 1 & 1 & 0 & 0 & 1 & 5 & 5 & 0 & 0 & 0 \\
\hline
\end{tabular}

[ ]: t-Statistic: significant parameters are in bold.

*Estimated by OLS in first differences: cointegration tests rejects the existence of at least one long run relationship. 
Appendix 5: Estimation Results of the Sectoral Import Functions for the Asian Countries - 1962-2006

\begin{tabular}{|c|c|c|c|c|c|c|c|c|c|c|c|c|}
\hline & Korea & & & & & & Malaysia* & & & & & \\
\hline \multirow{3}{*}{ LRER } & LMPRIM & LMRRNN & LMLTECH & LMMTECH & LMHTECH & LMOTHERS & LMPRIM & LMRRNN & LMLTECH & LMMTECH & LMHTECH & LMOTHERS \\
\hline & 0.079656 & -3.036711 & -0.245167 & 2.061276 & 16.52956 & -1.761099 & -1.769919 & -0.293941 & 0.323247 & 0.139108 & 0.642325 & 6.100515 \\
\hline & [0.09524] & {$[-2.52403]$} & {$[-0.66781]$} & {$[0.83770]$} & {$[0.76502]$} & {$[-3.67530]$} & {$[-2.11227]$} & {$[-1.32623]$} & [1.09096] & {$[0.32878]$} & [1.07551] & [3.19294] \\
\hline \multirow[t]{2}{*}{ LGDP } & 0.980197 & 1.25058 & 2.61413 & 1.942769 & 8.066641 & 1.900184 & 0.569921 & 1.24498 & 1.052196 & 1.282206 & 2.264001 & 0.843068 \\
\hline & [4.41777] & {$[6.82438]$} & [5.01139] & {$[5.18362]$} & {$[2.45113]$} & {$[26.0355]$} & {$[3.07559]$} & {$[25.4003]$} & [16.0579] & {$[13.7034]$} & {$[17.1417]$} & [1.99528] \\
\hline $\begin{array}{l}\text { Cointegration } \\
\text { Specification }\end{array}$ & 1 & 2 & 4 & 2 & 2 & 3 & 2 & 3 & 2 & 2 & 2 & 2 \\
\hline \multirow[t]{2}{*}{ Lag Structure } & 0 & 0 & 0 & 0 & 0 & 0 & 0 & 0 & 0 & 0 & 0 & 0 \\
\hline & Singapore & & & & & & Philippines & & & & & \\
\hline \multirow{3}{*}{ LRER } & LMPRIM & LMRRNN & LMLTECH & LMMTECH & LMHTECH & LMOTHERS & LMPRIM & LMRRNN & LMLTECH & LMMTECH & LMHTECH & LMOTHERS \\
\hline & -2.366035 & -4.361602 & -1.026651 & -0.685851 & -4.064687 & -0.73082 & -1.681269 & -0.945981 & -1.690542 & -1.891188 & 1.156874 & -3.089402 \\
\hline & {$[-0.74321]$} & [ - -2.94125$]$ & [- 2.12846] & [- 2.40516] & [- 1.48394] & [ -2.82918] & {$[-1.40807]$} & {$[-2.17180]$} & {$[-2.14159]$} & {$[-3.23851]$} & {$[0.41211]$} & {$[-0.63550]$} \\
\hline \multirow[t]{2}{*}{ LGDP } & 0.821058 & 0.908239 & 0.913069 & 2.674182 & 1.025817 & 0.886437 & 1.190461 & 1.591582 & 1.82742 & 1.532816 & 4.118471 & 1.485482 \\
\hline & [9.99244] & [21.7676] & [69.3224] & [9.90672] & {$[2.49716]$} & [23.5900] & [6.52713] & {$[13.6773]$} & {$[8.66528]$} & {$[9.82506]$} & [5.49158] & [2.00045] \\
\hline $\begin{array}{l}\text { Cointegration } \\
\text { Specification }\end{array}$ & 1 & 1 & 1 & 4 & 2 & 3 & 1 & 2 & 2 & 2 & 2 & 1 \\
\hline Lag Structure & 1 & 0 & 1 & 1 & 1 & 0 & 0 & 0 & 0 & 0 & 0 & 0 \\
\hline
\end{tabular}

[ ]: t-Statistic: significant parameters are in bold.

* 1964-2006 